\title{
KONSUMSI BUAH PEPAYA DALAM MENURUNKAN DEBRIS INDEKS PADA SISWA KELAS V DAN VI DI SDI BONTORAMBA
}

\author{
Jumriani, Ira Liasari
}

\begin{abstract}
ABSTRAK
Buah pepaya merupakan salah satu buah yang banyak mengandung nutrisi, vitamin, mineral,serat dan air. Selain dapat berguna untuk pencernaan dan kesehatan tubuh, pepaya juga sangat berguna dalam menjaga kesehatan gigi dan mulut karena pepaya memiliki kandungan serat dan air yang dapat membantu membersihkan gigi secara alami, sehingga luas permukaan debris yang terbentuk pada permukaan gigi dapat dikurangi dan pada akhirnya kerusakan gigi seperti karies bisa dicegah. Penelitian ini bertujuan untuk mengetahui pengaruh mengunyah buah pepaya dalam menurunkan debris indeks pada siswa kelas V dan VI di SDI Bonto Ramba. Metode penelitian yang dilakukan adalah eksperimental semu dengan pendekatan sebelum (pre) dan sesudah (post-test) perlakuan tanpa melakukan intervensi pada objek yang akan diteliti. Populasi adalah siswa kelas $\mathrm{V}$ dan VI di SDI Bontoramba. Dan sambel sebesar 40 siswa dengan menggunakan purposive sampling. Hasil penelitian ini menunjukkan adanya penurunan rata-rata debris indeks sebelum dan sesudah konsumsi buah papaya. ( $p$ value $=0,0001$ ). Dengan demikian dapat disimpulkan bahwa konsumsi buah papaya efektif dalam menurunkan debris indeks pada siswa kelas IV dan V di SDI Bonto Ramba
\end{abstract}

Kata kunci: Buah Pepaya, Debris Indeks

\section{PENDAHULUAN}

Kesehatan gigi dan mulut merupakan bagian kesehatan tubuh yang tidak dapat dipisahkan satu dengan yang lainnya. Masalah tingginya angka penyakit gigi dan mulut saat ini sangat dipengaruhi oleh beberapa faktor antara lain faktor perilaku masyarakat. Kesadaran masyarakat untuk datang berobat ke fasilitas pelayanan kesehatan masih rendah. Selain itu pemilihan pola makan yang salah dan pengaruh gaya hidup modern yang menyebabkan perubahan konsumsi pola makan dari makanan yang berserat menjadi makanan yang tidak berserat diperkirakan dapat mempengaruhi pertumbuhan rahang, sehingga mengakibatkan gigi tetap akan tumbuh berjejal. Dari hasil penelitian ada beberapa tempat yang kadar flournya nol seperti di Kalimantan, Sulawesi, dan Jambi sehingga prevalensi kariesnya tinggi.
(Herijulianti,dkk 2001). Hasil Riset Kesehatan Dasar (RISKESDAS) pada tahun 2013, menyatakan bahwa 25,9\% masyarakat Indonesia mengalami masalah gigi dan mulut dengan kelompok usia 10 - 14 tahun berkisar $25,2 \%$ dan untuk tingkat sekolah mencapai 27,0\%. (Riskesdas, 2013).

Salah satu faktor pendukung yang menyebabkan terjadinya karies gigi yaitu debris atau sisa-sisa makanan yang terdapat di sekitar gigi. Debris adalah material lunak yang terdapat pada permukaan gigi yang terdiri dari lapisan biofilm, material alba, dan sisa makanan. Debris mempunyai pengaruh yang cukup besar terhadap proses terjadinya karies. Luas permukaan debris dapat diukur dengan indeks debris. Indeks debris adalah skor debris yang menempel pada permukaan gigi penentu. Pengukuran indeks debris ini dilakukan untuk 
mengukur permukaan gigi yang ditutupi oleh debris.

Konsumsi buah yang segar dan kaya akan vitamin, mineral, serat dan air dapat melancarkan pembersihan sendiri pada gigi, sehingga luas permukaan debris dapat dikurangi dan pada akhirnya karies gigi dapat dicegah. Pepaya merupakan tanaman sumber vitamin, mineral, serat, karbohidrat dan mengandung enzim yang berguna untuk pencernaan. Berdasarkan hasil penelitian sebelumnya menunjukkan bahwa indeks debris siswa kelas $\mathrm{V}$ dan $\mathrm{VI}$ mengalami perubahan setelah mengonsumsi buah pepaya, yaitu terjadi perubahan indeks debris dari 24 orang $(60,0 \%)$ dengan kategori sedang menjadi 2 orang $(5,0 \%)$ dengan kategori sedang. (Chidhy MW, 2014).

Peneliti memilih buah pepaya sebagai bahan penelitian karena selain kandungan nutrisi, vitamin, dan serat yang terkandung di dalam buah pepaya sangat tinggi, juga karena harga yang murah, serta banyaknya masyarakat di Indonesia, khususnya di Gowa, yang menjadikan tanaman pepaya sebagai tanaman pekarangan. Buah pepaya yang digunakan peneliti yaitu buah pepaya masak yang berwarna merah dan segar.

Pemilihan anak kelas $\mathrm{V}$ dan $\mathrm{VI}$ yang berumur 10-12 tahun sebagai populasi karena pada kelompok usia ini minat belajar anak tinggi didukung oleh ingatan anak yang kuat serta kemampuan dalam menangkap dan memahami materi, dan informasi yang diberikan. Selain itu, pada pemeriksaan awal di SDI Bonto Ramba Kabupaten Gowa, didapatkan tingkat kebersihan gigi dan mulut rata-rata kategori sedang. Tujuan penelitian ini adalah untuk mengetahui pengaruh mengunyah buah pepaya dalam menurunkan debris indeks pada siswa kelas V dan VI di SDI Bonto Ramba Kabupaten Gowa.

\section{METODE PENELITIAN}

Penelitian yang dilakukan bersifat eksperimental yaitu suatu rancangan eksperimental semu dengan pendekatan sebelum (pre) dan sesudah (post-test) perlakuan tanpa melakukan intervensi pada objek yang akan diteliti. Penelitian ini dilakukan di SDI Bonto Ramba Kab. Gowa dilaksanakan pada bulan Agustus 2018. Populasi pada penelitian ini adalah seluruh siswa Kelas V dan VI SDI Bonto Ramba Kab. Gowa. Subjek dalam penelitian ini adalah siswa kelas $V$ dan VI sebanyak 40 siswa. Cara pengambilan subjek penelitian dilakukan dengan teknik total sampling dimana jumlah subjek penelitian sama dengan populasi.

Alat yang digunakan dalam penelitian ini adalah kaca mulut, sonde, senter (penerang), sarung tangan, nier bekken, kantung sampah, handuk putih, alat tulis dan kartu status. Bahan yang digunakan alkohol $70 \%$, betadine, tissue, kapas, pepaya masak. Pemeriksaan debris indeks pada subjek penelitian dilakukan sebelum diberi buah papaya. Pemeriksaan debris indeks menggunakan pengukuran debris indeks menurut Green dan Vermillion, yaitu dengan memeriksa tiga gigi rahang atas dan tiga gigi rahang bawah. Tiga gigi rahang atas yang diperiksa terdiri dari permukaan bukal molar pertama kanan dan kiri, serta permukaan labial 
gigi insisivus pertama kanan. Sedangkan untuk rahang bawah, yang diperiksa adalah permukaan lingual gigi molar pertama kiri dan kanan, serta permukaan labial gigi insisivus pertama kiri. Skor 0 diberikan jika tidak ada debris pada sonde setelah digoreskan ke permukaan $1 / 3$ servikal, skor 1 jika terdapat debris pada sepertiga permukaan gigi, skor 2 jika terdapat debris lebih dari $1 / 3$ tetapi tidak lebih dari 2/3 permukaan gigi, dan skor 3 jika terdapat debris di lebih dari dua pertiga permukaan gigi. Hasil dari pemeriksaan debris dikatan baik jika skor 0,0-0,6, sedang jika skor 0,7-1,8, dan buruk jika skor 1,9-3,0.
Setelah pemeriksaan debris indeks, subjek diberi buah papaya 100 gram dengan cara dikunyah sampai habis lalu diperiksa kembali debrisnya agar dapat dibandingkan perubahannya antara sebelum dan sesudah perlakuan. Semua data dikumpulkan lalu diolah dan disajikan dalam bentuk tabel kemudian dianalisis menggunakan uji $\mathrm{T}$.

\section{HASIL PENELITIAN}

Subjek penelitian ini terdiri dari 16 (40\%) orang siswa laki-laki dan 24 (60\%) orang siswa perempuan. Rentang usia subjek penelitian adalah $10-12$ tahun.

Tabel 1. Distribusi Frekuensi Hasil Pemeriksaan Sebelum Mengunyah Buah Pepaya

\begin{tabular}{|c|c|c|}
\hline Debris indeks & Frekuensi (n) & Persentase (\%) \\
\hline Baik & 5 & 12,5 \\
Sedang & 32 & 80,0 \\
Buruk & 3 & 7,5 \\
\hline Total & 40 & 100 \\
\hline
\end{tabular}

Tabel 2. Distribusi Frekuensi Hasil Pemeriksaan Sesudah Mengunyah Buah Pepaya

\begin{tabular}{|c|c|c|}
\hline Kategori & Frekuensi (n) & Persentase (\%) \\
\hline Baik & 32 & 80,0 \\
Sedang & 8 & 20,0 \\
Buruk & 0 & 0 \\
\hline Total & 40 & 100 \\
\hline
\end{tabular}

Tabel 3. Hasil Uji Beda Debris Indeks Sebelum dan Sesudah Mengunyah Buah Pepaya

\begin{tabular}{|c|c|c|c|}
\hline Sebelum & Sesudah & Selisih & P. Value \\
\hline Mean \pm SD & Mean \pm SD & Mean \pm SD & \\
$0,870 \pm 0,4274$ & $0,375 \pm 0,2133$ & $0,495 \pm 0.2141$ & 0,001 \\
\hline
\end{tabular}

Berdasarkan tabel 1, 2, dan 3 terlihat adanya penurunan debris indeks sebelum dan sesudah mengunyah buah papaya. Setelah dilakukan uji T berpasangan didapat $p$-value
0,001 yang artinya terdapat perbedaan bermakna antara debris indeks sebelum dan sesudah mengunyah buah papaya. 


\section{PEMBAHASAN}

Sikap dan perilaku anak mempunyai peran yang sangat besar terhadap status kesehatan anak tersebut. Anak-anak harus lebih rajin dan teliti dalam melakukan pembersihan gigi dan mulut, karena kebersihan gigi dan mulut yang tidak terjaga dapat menyebabkan terjadinya karies gigi. Salah satu sikap positif terhadap upaya-upaya pemeliharaan kesehatan gigi dan mulut adalah dengan mengkonsumsi buah papaya.

(Purba TR, 2011)

Hasil penelitian ini menunjukkan bahwa buah pepaya berpengaruh terhadap penurunan indeks debris. Hal ini dipengaruhi oleh serat yang terkandung di dalam buah pepaya. Serat adalah polisakarida nonpati yaitu karbohidrat kompleks yang terbentuk dari gugusan gula sederhana yang bergabung menjadi satu serta tidak dapat dicerna. Serat yang terkandung di dalam buah pepaya merupakan pembersih alamiah pada permukaan gigi geligi, dan juga dapat membantu menyingkirkan partikel-partikel makanan dan gula selama proses pengunyahan. Serat berperan untuk meningkatkan intensitas pengunyahan dalam mulut, sehingga proses pengunyahan makanan berserat ini akan merangsang dan meningkatkan produksi saliva. (Irene, 2009)

Serat makanan termasuk kategori zat non-gizi. Buah merupakan kandungan serat yang baik. Kandungan serat makanan pada buah 0,5-5 gram dalam 100 gram berat buah. Kebiasaan makan-makanan berserat tidak bersifat merangsang pembentukan debris, melainkan berperan sebagai pengendali secara alamiah.

Buah pepaya yang mengandung serat dan air akan bersifat membersihkan karena harus dikunyah terlebih dahulu dan dapat merangsang sekresi saliva. Di dalam saliva terdapat berbagai komponen yang dapat mencegah terjadinya karies gigi, yaitu dengan meng-hambat kolonisasi dan metabolisme bakteri serta membunuh bakteri. (Sitorus E, 2014)

Mengkonsumsi buah pepaya dengan kadar air dan serat yang mencukupi akan membantu pada orang yang memiliki kadar saliva yang sangat pekat dan sedikit karena akan lebih mudah untuk terjadinya lubang pada gigi dibandingkan dengan karakteristik orang yang memiliki kadar saliva lebih banyak. Pada dasarnya seseorang dengan kadar saliva pekat dan sedikit maka sisa makanan akan lebih mudah menempel pada permukaan gigi. Hasil penelitian ini juga sejalan dengan teori yang menyebutkan bahwa buah pepaya baik untuk dikonsumsi karena memiliki daya membersihkan gigi sendiri atau sering disebut dengan istilah self cleaning effect. (Cahyati $\mathrm{W}, 2013)$

Pada penelitian ini nilai debris mengalami penurunan sehingga dapat dikatakan mengunyah buah pepaya efektif menurunkan debris indeks. Hasil penelitian ini sejalan dengan penelitian yang dilakukan oleh Wanda Cindhy Mandalika (2014) tentang pengaruh konsumsi pepaya (Carica papaya) dalam menurunkan indeks debris pada anak usia 10-12 tahun di SDN 103 Manado yang menunjukkan bahwa ada penurunan indeks 
sebelum dan sesudah mengonsumsi buah pepaya. Hal ini berarti bahwa mengunyah buah pepaya untuk menurunkan debris indeks dapat dipraktekkan dalam keseharian murid-murid ini.

\section{KESIMPULAN}

Berdasarkan hasil penelitian mengenai pengaruh mengunyah buah pepaya dalam menurunkan debris indeks pada siswa kelas $\mathrm{V}$ dan VI di SDI Bonto Ramba, dapat ditarik kesimpulan bahwa mengkonsumsi buah pepaya dapat menurunkan debris indeks pada siswa kelas V dan VI di SDI Bonto Ramba.

\section{SARAN}

Pengetahuan tentang pentingnya kebersihan dan kesehatan gigi dan mulut sebaiknya diberikan sejak usia dini, demikian juga pengetahuan tentang manfaat dan kandungan gizi buah-buahan. Diharapkan pihak sekolah melalui program UKGS dapat memanfaatkan buah pepaya untuk dikonsumsi untuk menurunkan debris indeks sehingga dapat mencegah terjadinya karies gigi

\section{DAFTAR PUSTAKA}

Achmad H,2010. Trauma Gigi Anterior pada Anak, Penerbit Bimer, Makassar

Africa CWJ, Reddy J, 2013.The Association Between Gender and Tooth Loss in Small Rural Population of South Africa.

Astoeti TE, Boesro S,2011. Pengaruh Tingkat Pengetahuan terhadap kebersihan Gigi dan Mulut.Dentika Dental Journal.

Beal JF, 1996.Social Factor and Preventif Dentistry.St.Louis Mosby.
Hamrun N, 2010. Perbandingan Status Gizi dan karies Gigi pada murid SD Islam Athirah dan SD Bangkala III Makassar, Jurnal.

Handayani HF, 2010. Sifat Kariogenik pada Makanan Anak-anak Jurnal Dentofasial Kedokteran Gigi.

Hongini Yundali Siti, dan Aditiawarman, S.H., Hum. (2012). Kesehatan Gigi dan Mulut; Buku Lanjutan Dental Terminology. Bandung: Pustaka Reka Cipta

Irma,I.\& Intan A.S. 2013.Penyakit Gigi, Mulut dan THT Penyakit Gigi, Mulut dan THT Yogyakarta: Nuha Medika.

Kidd, Edwina dan Joyston Sally, 2013. DasarDasar Karies Penyakit dan Penanggulangan. Penerbit Buku Kedokteran EGC, Jakarta

Koesoemahardja $H, 2008$. Tumbuh Kembang Dentofasia Manusia, Penerbit Universitas Trisakti, Jakarta

Malik. 2008. Kesehatan Gigi danMulut : Laporan Kesehatan Badan Pengembangan Sistem Informasi dan Telematika Daerah (Bapesitelda) Provinsi Jawa Barat. Departemen Ortodonti Universitas Padjajaran: Bandung

Mumpuni, Y., \&Pratiwi, E. Masalah dan Solusi Penyakit Gigi dan Mulut, Rapha Publishing, Yogyakarta, 2013.

NarlanS, 2011. Dasar-Dasar Karies Penyakit dan Penanggulangannya, Penerbit Buku Kedokteran EGC, Jakarta.

Reilly Bo,2010. Socioeconomic Status and Oral Health, Journalod Australian Dental Association.

Tarigan Rasinta. (2013) Karies Gigi, Edisi 2. Jakarta: EGC.

Wangsarahardja K,2007. Kebutuhan Pelayanan Kesehatan Gigi dan Mulut Pada Mulut Pada Masyarakat Berpenghasilan Rendah, Scientific Journal In Dentistry.

WHO. 2012. The World Oral Health Report. http://www.who.int/mediacentre/factsh eets/fs318/en/ (Akses 26 Maret, 2016) 